\title{
Analisis Kinerja Keuangan Emiten Pengakuisisi Sebelum Dan Sesudah Akuisisi Periode 2013-2018
}

\author{
Mitha Herviana dan Herman Ruslim \\ Program Studi Manajemen Fakultas Ekonomi Universitas Tarumanagara, Jakarta \\ Email: mithahervianaa@gmail.com
}

\begin{abstract}
The purpose of this study is to analyze the financial performance of acquiring issuers before and after the acquisition. The method used in this study is descriptive comparative using secondary data to collage the data. The sample size used in this study was 32 sample companies. This study uses SPSS software by using purposive sampling, the findings of this study indicate that financial performance is proxied by that financial performance is proxied by liquidity ratios, profitability ratios, solvency ratios, activity ratios, market value ratios do not expreience significant changes between before and after the acquisition of the acquirer issuer.
\end{abstract}

Keywords : Financial Performance, Acquisition.

Abstrak: Tujuan dari penelitian ini adalah untuk menganalisis kinerja keuangan emiten pengakuisisi sebelum dan sesudah akuisisi. Metode yang digunakan dalam penelitian ini adalah deskriptif comparative dengan menggunakan data sekunder untuk mengumpulkan data. Ukuran sampel yang digunakan pada penelitian ini sebanyak 32 sampel perusahaan. Penelitian ini menggunakan software SPSS dengan menggunakan purposive sampling, temuan pada penelitian ini menunjukkan bahwa kinerja keuangan yang diproksikan dengan an bahwa kinerja keuangan yang diproksikan dengan rasio likuiditas, rasio solvabilitas, rasio profitabilitas, rasio aktivitas, rasio nilai pasar tidak mengalami perubahan yang signifikan antara sebelum dan sesudah akuisisi pada emiten pengakuisisi.

Kata Kunci : Kinerja Keuangan, Akuisisi.

\section{LATAR BELAKANG}

Di era globalisasi yang terjadi saat ini, persaingan usaha antar perusahaan menjadi semakin ketat. Persaingan tersebut berdampak kepada pemilik atau manajemen perusahaan sehingga membentuk perusahaan untuk terus berkompetitif menghadapi para pesaingnya. Perusahaan dapat menciptakan strategi bisnis yang baik dalam waktu jangka pendek maupun jangka panjang. Keberhasilan dari suatu perusahaan dapat dinilai dari bagaimana perusahaan tersebut dapat menghasilkan suatu keuntungan bagi perusahaan yang dapat meningkatkan nilai perusahaan.

Kondisi perekonomian global yang tidak stabil berdampak pada kesulitan perusahaan untuk dapat berkembang dalam perekonomian nasional maupun internasional terutama dalam dunia usaha untuk dapat mengembangkan usahanya, serta dapat mempertahankan kelangsungan kegiatan dari usaha. Menurut Aldy dan Yusuf (2015) ada dua cara pertumbuhan perusahaan yaitu dengan ekspansi internal dapat dilakukan dengan cara 
membangun bisnis dari awal yang memerlukan berbagai tahap untuk mendesain produk sebelum akhirnya produk diperjual belikan dan ekspansi eksternal dilakukan dengan cara membeli, menggabungkan atau mengambilalih perusahaan yang sudah ada.

Upaya-upaya yang dapat dilakukan perusahaan untuk meningkatkan kinerja keuangannya salah satunya yaitu dengan restrukturisasi. Bentuk-bentuk dari restrukturisasi yang dapat dilakukan oleh perusahaan yaitu dengan melakukan merger, akuisisi, konsolidasi, divestasi, going private, leverage buyout (LBO), dan juga spin-off. Kegiatankegiatan tersebut bertujuan untuk dapat memperbesar aset perusahaan dan memperluas pangsa pasar. Saat ini dunia sedang berjalan menuju era merger dan akuisisi. Alasan utama mengapa banyak perusahaan yang lebih memilih melakukan akuisisi karena cara ini merupakan cara yang lebih cepat agar dapat mencapai tujuan perusahaan dengan tidak memulai perusahaan dari awal. Tieka dan M. Ersyad (2018) fenomena akuisisi di Indonesia sudah tidak asing lagi bagi perusahaan yang sudah berkembang, akuisisi pun selalu mengalami peningkatan dalam beberapa tahun belakangan ini.

\section{KAJIAN TEORI}

Risna, Farida dan Annisa (2016) kinerja keuangan suatu perusahaan dapat diartikan sebagai suatu prospek atau masa depan, pertumbuhan dan potensi perkembangan yang baik bagi perusahaan. Menurut Rudianto (2013) kinerja keuangan adalah hasil atau prestasi yang telah dicapai oleh manajemen perusahaan dalam mengelola asset perusahaan secara efektif selama periode tertentu.

Menurut Josua Tarigan (2016) akuisisi merupakan salah satu jenis merger dimana salah satu perusahaan mengambil alih kepemilikan perusahaan lain sehingga meskipun nama target perusahaan tetap ada tetapi kepemilikannya telah beralih kepada perusahaan yang mengakuisisi. 


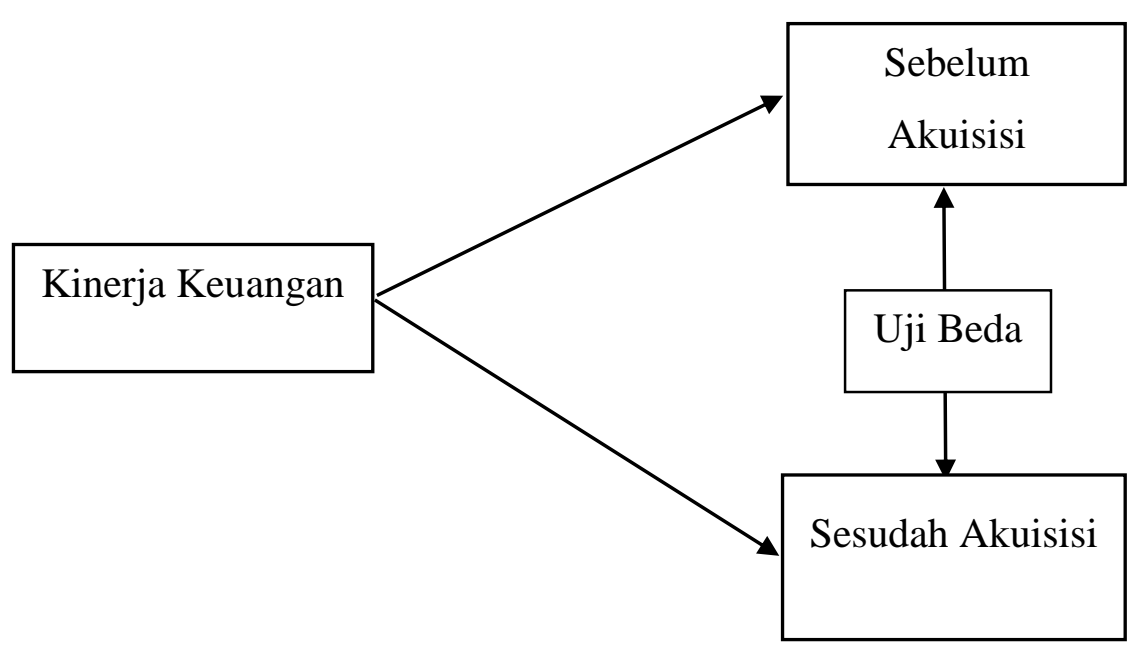

Dengan hipotesis sebagai berikut :

H1 : Terdapat perbedaan current ratio sebelum dan sesudah akuisisi bagi emiten pengakuisisi periode tahun 2013-2018.

$\mathrm{H} 2$ : Terdapat perbedaan debt to equity ratio sebelum dan sesudah akuisisi bagi emiten pengakuisisi periode tahun 2013-2018.

H3 : Terdapat perbedaan return on assets sebelum dan sesudah akuisisi bagi emiten pengakuisisi periode tahun 2013-2018.

H4 : Terdapat perbedaan total assets turn over sebelum dan sesudah akuisisi bagi emiten pengakuisisi periode tahun 2013-2018.

H5 : Terdapat perbedaan price to book value sebelum dan sesudah akuisisi bagi emiten pengakuisisi periode tahun 2013-2018.

\section{METODOLOGI}

Desain penelitian ini merupakan penelitian deskriptif komparatif, yaitu membandingkan rasio keuangan emiten pengakuisisi antara sebelum dan sesudah akuisisi. Data yang digunakan dalam penelitian ini adalah data sekunder. Data sekunder ini merupakan data yang berupa bukti, catatan, atau laporan historis yang telah tersusun dalam data, baik yang telah dipublikasikan maupun yang tidak dipublikasikan.

Populasi dalam penelitian ini adalah perusahaan yang melakukan akuisisi menurut data Komisi Pengawas Persaingan Usaha (KPPU). Populasi yang digunakan adalah perusahaan go public non-keuangan di Bursa Efek Indonesia (BEI). Populasi yang 
digunakan dalam penelitian ini adalah sejumlah 32 perusahaan go public non-keuangan di Bursa Efek Indonesia (BEI) yang melakukan akusisi periode tahun 2013 hingga 2018.

Data yang digunakan dalam penelitian adalah data yang bersifat kuantitatif. Data yang digunakan merupakan data silang (cross section). Pengambilan sampel dalam penelitian ini menggunakan metode purposive sampling atau judgement sampling. Untuk menganalisis data yang telah diperoleh dalam penelitian menggunakan software spss statistics 25 dengan uji statistika.

Hasil uji statistik. Untuk menguji normalitas data dalam penelitian ini digunakan uji kolmogorov smirnov. Karena sampel data kurang dari 50 data, maka untuk hasil perhitungan dapat memperhatikan hasil dari perhitungan shapiro-wilk.

Tabel 1. Hasil uji normalitas emiten pengakuisisi sebelum dan sesudah akuisisi periode 2013-2018

\begin{tabular}{|c|c|c|c|c|c|c|c|}
\hline & \multicolumn{9}{|c|}{ Tests of Normality } \\
\hline & Statistic & df & Sig. & Statistic & df & Sig. & \\
\cline { 2 - 8 } CR_Sebelum &, 212 & 32 &, 001 &, 809 & 32 &, 000 & $\begin{array}{c}\text { Tidak } \\
\text { Normal }\end{array}$ \\
\hline CR_Sesudah &, 205 & 32 &, 001 &, 733 & 32 &, 000 & $\begin{array}{c}\text { Tidak } \\
\text { Normal }\end{array}$ \\
\hline DER_Sebelum &, 285 & 32 &, 000 &, 596 & 32 &, 000 & $\begin{array}{c}\text { Tidak } \\
\text { Normal }\end{array}$ \\
\hline DER_Sesudah &, 184 & 32 &, 007 &, 795 & 32 &, 000 & $\begin{array}{c}\text { Tidak } \\
\text { Normal }\end{array}$ \\
\hline ROA_Sebelum &, 151 & 32 &, 061 &, 947 & 32 &, 120 & Normal \\
\hline ROA_Sesudah &, 214 & 32 &, 001 &, 717 & 32 &, 000 & $\begin{array}{c}\text { Tidak } \\
\text { Normal }\end{array}$ \\
\hline TATO_Sebelum &, 207 & 32 &, 001 &, 830 & 32 &, 000 & $\begin{array}{c}\text { Tidak } \\
\text { Normal }\end{array}$ \\
\hline TATO_Sesudah &, 233 & 32 &, 000 &, 760 & 32 &, 000 & $\begin{array}{c}\text { Tidak } \\
\text { Normal }\end{array}$ \\
\hline PBV_Sebelum &, 229 & 32 &, 000 &, 606 & 32 &, 000 & $\begin{array}{c}\text { Tidak } \\
\text { Normal }\end{array}$ \\
\hline PBV_Sesudah &, 255 & 32 &, 000 &, 688 & 32 &, 000 & $\begin{array}{c}\text { Tidak } \\
\text { Normal }\end{array}$ \\
\hline
\end{tabular}

Sumber : data sekunder diolah, 2019

Data kinerja keuangan yang diukur dengan rasio likuiditas, rasio solvabilitas, rasio profitabilitas, rasio aktivitas, rasio nilai pasar menunjukkan bahwa data tidak terdistribusi dengan normal. 
Tabel 2. Hasil uji wilcoxon signed ranks test kinerja keuangan emiten pengakuisisi sebelum dan sesudah akuisisi periode tahun 2013-2018

\begin{tabular}{|c|c|c|c|c|c|}
\hline \multicolumn{7}{|c|}{ Test Statistics } \\
\hline & $\begin{array}{c}\text { CR_Sesudah } \\
- \\
\text { CR_Sebelum }\end{array}$ & $\begin{array}{c}\text { DER_Sesudah } \\
-\end{array}$ & $\begin{array}{c}\text { ROA_Sesudah } \\
-\end{array}$ & $\begin{array}{c}\text { TATO_Sesudah } \\
-\end{array}$ & $\begin{array}{c}\text { PBV_Sesudah } \\
-\end{array}$ \\
\hline Z &,- 860 & $-1,496$ & $-1,744$ &,- 775 & $-1,254$ \\
\hline $\begin{array}{c}\text { Asymp. } \\
\begin{array}{c}\text { Sig. (2- } \\
\text { tailed) }\end{array}\end{array}$ &, 390 &, 135 &, 081 &, 438 &, 210 \\
\hline
\end{tabular}

Sumber : data sekunder diolah, 2019

a. Tidak terdapat perbedaan rasio likuiditas yang diproksikan dengan current ratio emiten pengakuisisi antara satu tahun sebelum dan satu tahun sesudah akuisisi.

b. Tidak terdapat perbedaan rasio solvabilitas yang diproksikan dengan debt to equity ratio emiten pengakuisisi antara satu tahun sebelum akuisisi dan satu tahun sesudah akuisisi.

c. Tidak terdapat perbedaan rasio profitabilitas yang diproksikan dengan return on assets emiten pengakuisisi antara satu tahun sebelum dan satu tahun sesudah akuisisi.

d. Tidak terdapat perbedaan rasio aktivitas yang diproksikan dengan total assets turnover emiten pengakuisisi antara satu tahun sebelum dan satu tahun sesudah akuisisi.

e. Tidak terdapat perbedaan rasio nilai pasar yang diproksikan dengan price to book value emiten pengakuisisi antara satu tahun sebelum dan satu tahun sesudah akuisisi.

\section{DISKUSI}

Rasio likuiditas. Dari hasil analisis menunjukkan bahwa rasio likuiditas yag diproksikan dengan variabel current ratio pada emiten pengakuisisi tidak terdapat perbedaan kinerja keuangan antara satu tahun sebelum akuisisi dengan satu tahun sesudah akuisisi. Hal ini dapat dilihat dari hasil pengujian yaitu current ratio memiliki nilai signifikasi sebesar 0,390 (lebih besar dari 0,05). Maka, hal ini membuktikan bahwa akuisisi tidak memiliki pengaruh yang berarti terhadap kemampuan perusahaan dalam memenuhi kewajiban jangka pendeknya dengan menggunakan aset lancar yang tersedia, sehingga menghasilkan nilai current ratio yang tidak jauh berbeda antara sebelum akuisisi dan sesudah akuisisi.

Rasio solvabilitas. Dari hasil analisis menunjukkan bahwa rasio solvabilitas yang diproksikan dengan variabel debt to equity ratio pada emiten pengakuisisi tidak terdapat perbedaan kinerja keuangan antara satu tahun sebelum akuisisi dengan satu tahun sesudah akusiisi. Hal ini dapat dilihat dari hasil pengujian yaitu debt to equity ratio memiliki nilai signifikansi sebesar 0,135 (lebih besar dari 0,05). Hal ini dapat terjadi dikarenakan, perusahaan belum dapat menutupi kewajiban lancarnya dalam jangka pendek dan membutuhkan waktu yang lebih lama sehingga akuisisi tidak memiliki pengaruh yang berarti terhadap rasio solvabilitas.

Rasio profitabilitas. Dari hasil analisis menunjukkan bahwa rasio profitabilitas yang diproksikan dengan variabel return on assets pada emiten pengakuisisi tidak terdapat perbedaan kinerja keuangan antara satu tahun sebelum akuisisi dengan satu tahun sesudah 
akuisisi. Hal ini dapat dilihat dari hasil pengujian yaitu return on assets memiliki nilai signifikansi sebesar 0,081 (lebih besar dari 0,05). Hal ini menunjukkan bahwa akuisisi belum memberikan pengaruh terhadap profitabilitas sehingga akuisisi belum mencipatakan sinergi yang diharapkan. Karena sinergi yang diharapkan dapat meningkatkan keuntungan perusahaan.

Rasio aktivitas. Dari hasil analisis menunjukkan bahwa rasio aktivitas yang diproksikan dengan variabel total assets turnover pada emiten pengakuisisi tidak terdapat perbedaan kinerja keuangan antara satu tahun sebelum akuisisi dengan satu tahun sesudah akuisisi. Hal ini dapat dilihat dari hasil pengujian yaitu total assets turnover memiliki nilai signifikansi sebesar 0,438 (lebih besar dari 0,05). Hal ini menunjukkan bahwa akuisisi tidak memiliki pengaruh yang signifikan pada efisiensi perusahaan dalam menggunakan asetnya untuk menghasilkan penjualan belum optimal.

Rasio nilai pasar. Dari hasil analisis menunjukkan bahwa rasio nilai pasar yang diproksikan dengan price to book value pada emiten pengakuisisi tidak terdapat perbedaan kinerja keuangan antara satu tahun sebelum akuisisi dengan satu tahun sesudah akuisisi. Hal ini dapat dilihat dari hasil pengujian yaitu price to book value memiliki nilai signifikansi sebesar 0,210 (lebih besar dari 0,05). Hal ini menunjukkan bahwa akuisisi tidak memiliki pengaruh yang signifikan terhadap penilaian harga saham perusahaan.

\section{KESIMPULAN}

Berdasarkan hasil dari analisis data mengenai perbedaan kinerja keuangan emiten pengakuisisi sebelum dan sesudah akuisisi periode tahun 2013-2018 yang telah diuraikan pada bab sebelumnya, maka dapat ditarik kesimpulan sebagai berikut : (1) Hasil analisis pada emiten pengakuisisi periode tahun 2013-2018 untuk satu tahun sebelum dan satu tahun sesudah akuisisi dengan variabel rasio likuiditas yang diproksikan dengan current asset adalah hasil dari uji statistik deskriptif menunjukkan bahwa current ratio mengalami kenaikan setelah melakukan akuisisi. Dan kinerja keuangan emiten pengakuisisi menunjukkan bahwa tidak terdapat perbedaan yang signifikan antara sebelum dan sesudah akuisisi. (2) Hasil analisis pada emiten pengakuisisi periode tahun 2013-2018 untuk satu tahun sebelum dan satu tahun sesudah akuisisi dengan variabel rasio solvabilitas yang diproksikan dengan debt to equity ratio adalah hasil dari uji statistik deskriptif menunjukkan bahwa debt to equity ratio mengalami penurunan setelah melakukan akuisisi. Dan kinerja keuangan emiten pengakuisisi menunjukkan bahwa tidak terdapat perbedaan yang signifikan antara sebelum dan sesudah akuisisi. (3) Hasil analisis pada emiten pengakuisisi periode tahun 2013-2018 untuk satu tahun sebelum dan satu tahun sesudah akuisisi dengan variabel rasio profitabilitas yang diproksikan dengan return on assets adalah hasil dari uji statistik deskriptif menunjukkan bahwa return on assets mengalami penurunan setelah akuisisi. Dan kinerja keuangan emiten pengakuisisi menunjukkan bahwa tidak terdapat perbedaan yang signifikan antara sebelum dan sesudah akuisisi. (4) Hasil analisis pada emiten pengakuisisi periode tahun 2013-2018 untuk satu tahun sebelum dan satu tahun sesudah akuisisi dengan variabel rasio aktivitas yang diproksikan dengan total assets turnover adalah hasil dari uji 
statistik deskriptif menunjukkan bahwa total assets turnover mengalami penurunan. Dan kinerja keuangan emiten pengakuisisi menunjukkan bahwa tidak terdapat perbedaan yang signifikan antara sebelum dan sesudah akuisisi. (5) Hasil analisis pada emiten pengakuisisi periode tahun 2013-2018 untuk satu tahun sebelum dan satu tahun sesudah akuisisi dengan variabel rasio nilai pasar yang diproksikan dengan price to book value adalah hasil dari uji statistik deskriptif menunjukkan bahwa price to book value mengalami penurunan. Dan kinerja keuangan emiten pengakuisisi menunjukkan bahwa tidak terdapat perbedaan yang signifikan antara sebelum dan sesudah akuisisi.

\section{DAFTAR PUSTAKA}

Akolaa, Andrews Adugudaa (2018). Foreign Market Entry Through Acquisition and Firm Financial Performance Empirical : Evidence From Ghana. International Journal of Emerging Markets, 13(5), 1348-1371.

Aprilita, Ira, Rina Tjandrakirana, \& Aspa Hani (2013). Analisis Perbandingan Kinerja Keuangan Perusahaan Sebelum dan Sesudah Akuisisi (Studi Pada Perusahaan Pengakuisisi yang Terdaftar di BEI periode 2000-2011). Jurnal Manajemen dan Bisnis Sriwijaya, 11(2), 99-114.

Asril, Juli, Imas Rosidawati, \& Ahmad M. Ridwan (2018). Konsep Akuisisi Saham Perusahaan Nasional. Bandung : Aria Mandiri Group.

Azhari, Aldy \& Yusuf Budiana (2015). Analisis Perbandingan Kinerja Keuangan Sebelum dan Sesudah Akuisisi (Studi Kasus Pada Perusahaan yang Melakukan Akuisisi Tahun 2011). E-proceeding of management, 2(3), 2753-2759).

Esterlina, Prisya \& Nila Nuzula (2017). Analisis Kinerja Keuangan Perusahaan Sebelum dan Sesudah Merger dan Akuisisi. Jurnal Administrasi Bisnis, 47(2), 39-48.

Eugene, Brigham F., \& Houston Joel F. (2014). Dasar-Dasar Manajemen Keuangan buku 1. Jakarta : PT Grasindo.

Gustyana, Tieka Trikartika \& H.M. Ersyad (2018). Analisis Perbandingan Kinerja Keuangan Antara Sebelum dan Sesudah Akuisisi pada Perusahaan Pengakuisisi (Studi Kasus pada Perusahaan Publik yang Melakukan Akuisisi tahun 2013-2015). E-Proceeding of Management, 5(1), 171-176.

Hery (2014). Analisis Kinerja Manajemen. Jakarta : PT Grasindo.

Ismail, Fajri (2018). Statistika Untuk Penelitian Pendidikan dan Ilmu-Ilmu Sosial. Jakarta : Prenadamedia Group.

Kusumaningtyas, Reza \& Siti Ragil (2018). Analisis Rasio Untuk Mengukur Kinerja Keuangan Sebelum dan Sesudah Melakukan Akuisisi (Studi Kasus Pada PT Alam Sutera Realty Tbk Periode 2008-2016). Jurnal Administrasi Bisnis, 65(1), 74-82.

Mahadewi, Anak Agung \& I Putu Sudana (2017). Kinerja Keuangan Bidder Firm Sebelum dan Sesudah Penggabungan Usaha. E-Jurnal Manajemen Unud, 6(1), 674-698.

Muchson (2017). Statistik Deskriptif. Bogor : Guepedia.

Nasir, Munawir \& Tiara Morina (2018). Analisis Perbandingan Kinerja Keuangan Pada Perusahaan Sebelum dan Sesudah Merger dan Akuisisi (Studi Perusahaan yang Melakukan Merger dan Akuisisi yang Terdaftar di BEI 2013-2015). Economic Resource, 1(1), 71-85.

Nugroho, Susanti Adi (2014). Hukum Persaingan Usaha di Indonesia. Jakarta : PT Fajar Interpratama Mandiri. 
Novaliza, Putri \& Atik Djajanti (2013). Analisis Pengaruh Merger dan Akuisisi Terhadap Kinerja Perusahaan Publik di Indonesia (Periode 2004-2011). Jurnal Akuntansi dan Bisnis, 1(1), 1-16.

Oktaviani, Anria Gusnelly \& Budi Rustandi (2015). Analisis Perbandingan Kinerja Keuangan Perusahaan Sebelum dan Sesudah Akuisisi pada Perusahaan yang Terdaftar di Bursa Efek Indonesia Tahun 2011. E-Proceeding of Management, 2(2), 1909-1916.

Pratiwi, Putu Reisa \& I. B. Panji Sedana (2017). Analisis Kinerja Keuangan Perusahaan Multinasional Sebelum dan Sesudah Akuisisi (Studi Perusahaan Multinasional Pengakuisisi di BEI). E-Jurnal Manajemen Unud, 6(1), 235-263.

Rahayu, Sinta \& Diah Lestari (2018). Perbedaan Kinerja Keuangan Sebelum dengan Sesudah Akuisisi Terhadap Perusahaan yang Terdaftar di BEI. Jurnal Manajemen Dewantara, 2(2), 122-127.

Rani, Neelam, Surendra S. Yadav, \& P.K. Jain (2015). Financial Performance Analysis of Mergers and Acquisitions : Evidence From India. International Journal of Commerce and Management, 25(4), 402-423.

Ross, Stephen A., Randolph W., Bradford D., et. All (2015). Pengantar Keuangan Perusahaan Buku 1. Jakarta : Salemba Empat.

Rudianto (2013). Akuntansi Manajemen Informasi Untuk Pengambilan Keputusan Strategis. Jakarta : Erlangga.

Sitanggang, J.P. (2013). Manajemen Keuangan Perusahaan Lanjutan. Jakarta : Mitra Wacana Media.

Surjarweni, V. Wiratna (2017). Analisis Laporan Keuangan Teori, Aplikasi, dan Hasil Penelitian. Yogyakarta : Pustaka Baru Press.

Susana, Risna, Farida Titik, \& Annisa Nurbaiti (2016). Analisis Perbandingan Kinerja Keuangan Sebelum dan Sesudah Akuisisi Pada Perusahaan Pengakuisisi (Studi Kasus Pada Perusahaan Publik Non-Keuangan yang Terdaftar di Bursa Efek Indonesia Tahun 2013-2014). E-Proceeding of Management, 3(3), 3358-3365.

Tarigan, Josua, Swenjiadi Yenewan, \& Grace Natalia (2016). Meger dan Akuisisi dari Perspektif Strategis dan Kondisi Indonesia (Pendekatan Konsep dan Studi Kasus). Yogyakarta : Ekuilibria.

Timotius, Kris H (2017). Pengantar Metodologi Penelitian (Pendekatan Manajemen Pengetahuan Untuk Perkembangan Pengetahuan). Yogyakarta : Penerbit Andi.

www.idx.co.id

www.kppu.go.id 